\title{
Optimum Reserves in Vietnam Based on the Approach of Cost-Benefit for Holding Reserves and Sovereign Risk
}

\author{
Thinh Vuong TRAN*, Thao Phan Thi Dieu LE ${ }^{* *}$ \\ Received: December 19, 2019 Revised: January 31, 2020 Accepted: February 06, 2020.
}

\begin{abstract}
This paper estimates the optimum level of reserves in Vietnam based on the approach of reserves' cost-benefit and sovereign risk which is one of developing countries' characteristics. The cost of reserves is the opportunity cost when holding reserves. The benefit of reserves is the loss due to country's default in case that there is no reserves to finance external debt payment. The optimum reserves is found out by minimizing the total of opportunity cost and loss due to country's default with the probability of default. Through the usage of HP Filter method for calculating the loss due to country's default, ARDL regression for the risk premium model and lending rate of VND as proxy for opportunity cost together with the Vietnamese economic data in the period of 2005 - 2017, the empirical results show that the optimum reserves in Vietnam is almost higher than the actual reserves during the research period except the point of Q3/2008 and the last point of research period - Q4/2017. Therefore, Vietnam should continue to increase reserves for safety but Vietnam does not need pushing quickly the speed of increasing reserves. In addition, controlling Vietnamese optimum reserves is necessary to help the actual reserves become reasonable.
\end{abstract}

Keywords : Reserves, Optimum Reserves, Probability of Default.

JEL Classification Code : F31, C32, C51.

\section{Introduction}

Reserves is always an important matter to any governments in the world. The recent financial crises proved the importance of reserves because it is one of country's defensive weapons and is also the "buffer stock" to prevent external shocks, helping country managing large capital outflows without spending the expensive costs (IMF, 2011). In the 1997 Asian financial crisis, the Thai baht depreciates up to $83.21 \%$ within the short time, from Q2/2007 to Q4/2007 (Yu, 2018). This serious depreciation originates from the reserves shortage to support the liquidity for the capital flows drawn out of Thailand. Therefore, according to reserves data of International

*First Author and Corresponding Author. Lecturer, Faculty of Banking, Banking University Ho Chi Minh City, Vietnam [Postal Address: 67 No. 28 Street, Quarter 4, Hiep Binh Chanh Ward, Thu Duc District, Ho Chi Minh City, 700000, Vietnam].

Email: thinhtv@buh.edu.vn or trvuongthinh@yahoo.com.

${ }^{* *}$ Associate Professor, Faculty of Finance, Banking University Ho Chi Minh City, Vietnam. Email: thaolptd@buh.edu.vn

(c) Copyright: The Author(s)

This is an Open Access article distributed under the terms of the Creative Commons Attribution NonCommercial License (https://creativecommons.org/licenses/by-nc/4.0/) which permits unrestricted noncommercial use, distribution, and reproduction in any medium, provided the original work is properly cited.
Financial Statistics (IFS) in 2018, the world reserves have been increasing quickly, from 2,239 billion USD in 2000 up to 12,663 billion USD in 2017 . Vietnam is certainly in this trend due to the recognition of reserves' importance. Especially after the financial crisis in 2008, Vietnamese reserves raises sharply. According to reserves data of IFS in 2018, within only seven years from 2010 to 2017, Vietnamese reserves increases more 36.5 billion USD.

However, according to Calvo, Izquierdo and Loo-Kung (2012), although reserves is larger, it is easier to prevent sudden shocks in country's self-protective strategy, but increasing reserves too much maybe reaches the critical point and makes the marginal income of reserves drop sharply, so becoming "excessive" reserves. Actually, holding too much reserves can create the costly expense because reserves' profit is much lower than the profit of ordinary capitals with the higher risk. This means that holding more reserves can makes the larger cost of holding and that is reserves' opportunity cost. Moreover, IMF (2012) affirms that the excessive reserves can causes the long imbalance of the world economy as per Triffin's Dilemma and destroys the stability of world currency system. In fact, Guan and Lau (2018) indicate that Triffin's Dilemma exists 
in the long run after re-examining by the data set of four currencies (USD, JPY, EUR and GBP) from 1973 to 2013. This affirms more the instability of world currency system from accumulating reserves excessively. Hence, it is necessary for IMF to help countries as its members decreasing the excessive reserves. Countries only need to cumulate reserves at the adequate or optimum level. According to Oputa and Ogunleye (2010), the optimum reserves is the reserves which can ensure the withstanding ability of balance of payments and the consequence of adjustment in macroeconomic factors when facing the external price shocks or the reverse foreign short-term capital flow.

With the above important meaning of optimum reserves, there are many researches using many different methods and models to estimate a nation's optimum reserves. In these models, the one of Ben-Bassat and Gottlieb (1992) estimates optimum reserves based on the approach of costbenefit from holding reserves. This paper determines to apply this model to estimate the Vietnamese optimum reserves because this model including sovereign risk is very suitable for developing countries. The estimated optimum reserves is compared with the actual reserves to decide whether Vietnam should continue to increase reserves. The rest of this paper is organised as follows: section 2 and 3 describes literature review and methodology; section 4 shows results and discussion; section 5 addresses conclusions and policy implications.

\section{Literature Review}

Heller (1966) firstly proposes the approach of costbenefit from holding reserves to estimate the optimum reserves and says that the optimum reserves is the reserves at which the marginal benefit equals to marginal cost for holding reserves. The benefit from holding reserves is for financing to avoid the deficit in balance of payments and then, it can avoid paying expenses to adjust the equilibrium in balance of payments. In the other words, the benefit from holding reserves is the cost of adjustment. For the cost from holding reserves, it is opportunity cost which is the difference between income of investing reserves as the ordinary capital and income of investing reserves in fact. Therefore, the optimum reserves can be estimated by minimizing the total of adjustment cost and opportunity cost. However, Heller (1966) is not yet exact in supposing that the probability function in case of deficit in balance of payments does not concern with reserves.

Applying to the method of Heller (1966), Ben-Bassat and Gottlieb (1992) built the optimum reserves model including sovereign risk. The sovereign risk in this model is the risk which a country cannot make payment for its external debts due to economic, political or legal reasons. This risk often happens in developing countries and emerging economies, so when lending or investing in these countries, investors must accept the existence of sovereign risk. Accordingly, the model of Ben-Bassat and Gottlieb (1992) is very suitable for developing and emerging countries. Ben-Bassat and Gottlieb (1992) use the Israel's yearly data in the period of 1964 - 1988 in order to build the optimum reserves model for Israel. The result is that the Israel's optimum reserves is almost lower than the actual reserves during this period.

Ozyildirim and Yaman (2005) base on the model of BenBassat and Gottlieb (1992) and use the quarterly data from Q1/1988 to Q4/2002 to build the optimum reserves model for Turkey. The empirical result shows that even at the lowest output loss of 5\% GDP, the optimum reserves is also higher than the actual one. Consequently, Turkey needs to increase more reserves in order to prevent sudden shocks and avoid sovereign risk. Tecnica (2012) also applies the model of Ben-Bassat and Gottlieb (1992) and selects the quarterly data in the period of Q2/1995 - Q1/2012 to estimate the Colombia's optimum reserves. The estimation result of optimum reserves is 34.09 billion USD in the latest quarter of research period - Q1/2012 - at the output loss of $10 \%$ GDP, close to the actual reserves of 31.909 billion USD. Prabheesh (2013) uses the model of BenBassat and Gottlieb (1992) to estimate the India's optimum reserves basing on the quarterly data of Q2/1994 to $\mathrm{Q} 4 / 2009$. The result shows that the optimum reserves is almost lower than the actual ones during the period, except 1997 - 1998. This means that the Indian government can use the excess of reserves comparing to the optimum reserves for necessary economic activities. Tule, Egbuna, Sagbamah, Abdusalam, Ogundele, and Oduyemi (2015), belonging to Central Bank of Nigeria, also base on the model of Ben-Bassat and Gottlieb (1992) along with the method of variable calculation of Prabheesh (2013) to find out the Nigeria's optimum reserves. With the Nigerian quarterly data of Q1/2000 - Q1/2014, the empirical result shows that the Nigeria's optimum reserves is lower than the actual one.

\section{Research Methodology}

\subsection{Theoretical Model}

Ben-Bassat and Gottlieb (1992) present that reserves only depletes when sovereign risk happens. Then, the government cannot pay all external debts although it use all reserves for financing and so it comes the default. Thus, probability of depleting reserves is also similar to probability of default due to a country's non-payment of 
external debts.

Applying the method of cost-benefit from holding reserves of Heller (1966), Ben-Bassat and Gottlieb (1992) express that the central bank tries to minimize the total cost of reserves including the loss of income (opportunity cost) when holding reserves in case that reserves amount is higher than zero and the loss due to country's default in case of depleting reserves or being zero for reserves. The loss due to country's default represents the benefit from holding reserves. The function of total cost when holding reserves is described as follows:

$$
E C=\pi C_{0}+(1-\pi) C_{1}
$$

with: $E C$ : the expected total cost of reserves; $C_{0}$ : the loss due to country's default when reserves amount is equal to zero; $\mathrm{C}_{1}$ : the loss of income (opportunity cost) when reserves amount is higher than zero; $\pi$ : the probability of default (probability of being zero for reserves); $(1-\pi)$ : the probability of being higher than zero for reserves.

\subsubsection{Opportunity Cost}

The loss of income is calculated on the formula:

$$
\mathrm{C}_{1}=\mathrm{rR}
$$

with: $\mathrm{C}_{1}$ : the loss of income; $\mathrm{r}$ : opportunity cost; $\mathrm{R}$ : reserves.

Basing on the meaning of opportunity cost, empirical researches measure opportunity cost by only one interest rate or the difference of two interest rates representing the profit of non-risk assets and risky ordinary assets. However, almost researches choose the method of measuring opportunity cost by only one interest rate. For examples, Ozyildirim and Yaman (2005) takes the Turkey's international borrowing rate as opportunity cost when estimating the Turkey's optimum reserves. Prabheesh (2013) estimates the India's optimum reserves with the selection of India's 91-day Treasury Bill yield rate as proxy for opportunity cost. Tule et al. (2015) also choose Nigeria's 90-day Treasury Bill rate as opportunity cost.

Accordingly, when estimating the Vietnam's optimum reserves, this paper determines to select the lending rate of VND as proxy for opportunity cost. Thus, opportunity cost in this case is the largest in order to emphasize that increase of reserves is the important matter and Vietnam needs to consider carefully when deciding in increase of reserves.

\subsubsection{The Loss due to Country's Default}

Ben-Bassat and Gottlieb (1992) represent that most of developing countries must borrow from the international financial market and hence, they always need an available determined amount of reserves for maintaining their creditworthiness. The sudden depletion of reserves decreases their creditworthiness, the cost of borrowing is higher as well as the credit supply for them is also lower. Consequently, the default crisis maybe happens and causes a drop in country output or GDP. Therefore, the loss due to default or the cost due to depletion of reserves is similar to the loss of GDP due to default. Ben-Bassat and Gottlieb (1992) calculate the potential GDP of some years after the default year with the supposition is that the growth speed of GDP still goes forward continuously without default. This growth speed can be measured by making average of growth speed in some years before default. The loss of GDP or the loss due to country's default is equal to the total difference between actual GDP and potential GDP during the period of dropped growth speed of GDP after default.

However, if a country never happens default, empirical researches of Prabheesh (2013) and Tule et al. (2015) choose the time of domestic or world crisis which decreases the growth speed of GDP for calculating the loss due to country's default. Because Vietnam does not yet face to default crisis, this paper bases on the recent financial crisis in 2008 which makes a drop in Vietnam's growth speed during Q1/2008 - Q2/2013 in order to estimate the loss of Vietnamese GDP as proxy for the loss due to country's default.

\subsubsection{Probability of Default}

If a country's reserves is high, it is easy for this country to borrow at the international financial market. In other words, the possibility of non-payment for external debts is difficult to happen or the probability of default reduces. This means that probability of default is influenced by reserves and makes the negative relationship. Besides, probability of default or default risk is influenced by many other fundamental economic factors. In summary, probability of default is the function of reserves and set of influenceable economic variables and is described as follows:

$$
\pi=f(R, Z) \text { and } \frac{\partial \pi}{\partial R}=\pi_{\mathrm{R}}<0
$$

in which: R: reserves; $Z$ : set of economic variables influencing on probability of default; $\pi_{R}$ : marginal probability of default, being derivative of $\pi$ based on R and $\pi_{\mathrm{R}}<0$ means the negative relationship between reserves and probability of default.

The calculation method of probability of default is based on the premium when a country borrow at the international market. This is the tool of measuring default risk (Ozyildirim \& Yaman, 2005). The international market evaluates country's probability of default, puts it in the premium and makes the difference between interest rate of $\boldsymbol{i}$ for risky countries and rate of $i^{*}$ for debts without risk such as LIBOR. According to expectation theory, when lending 
risky countries, investors expect that if the default does not happen at these countries (in case of $1-\pi$ ), the income is equal to the one gaining from debts without risk. It means that:

$$
(1-\pi)(1+i)=1+i^{*}
$$

With the equation (4), risk premium $\left(\frac{i-i^{*}}{1+i^{*}}\right)$ can be rewritten:

$$
\frac{\pi}{1-\pi}=\frac{i-i^{*}}{1+i^{*}}
$$

Meanwhile, Ben-Bassat and Gottlieb (1992) say that the use of logistic probability function to calculate probability of default by is very suitable because this function shows the influence on probability of default from set of economic variables. Basing on logistic probability function, probability of default is described as follows:

$$
\pi=\frac{e^{\mathrm{f}}}{1+e^{\mathrm{f}}} \quad \text { or } \quad \frac{\pi}{1-\pi}=e^{\mathrm{f}}
$$

in which $\mathrm{f}$ is determined at the equation (3).

At the same time, the equation (6) can be expressed in another way:

$$
\ln \left(\frac{\pi}{1-\pi}\right)=\ln \left(e^{f}\right)=f
$$

or according to the equation (5):

$$
\ln \left(\frac{i-i^{*}}{1+i^{*}}\right)=f
$$

According to Ozyildirim and Yaman (2005), Tecnica (2012), Prabheesh (2013) and Tule et al. (2015) along with the availability of Vietnam data, set of economic variables influencing probability of default in this paper includes trade openness measured by the ratio of import value/ GDP, the volatility of foreign portfolio investment, the ratio of short-term external debt/ reserves and the ratio of fiscal deficit/ GDP. Vietnam's state budget expenditure reaches to $25 \%-35 \%$ of GDP while there are not many items to continue to increase the state budget revenue, so it is very difficult to balance Vietnam's state budget (Nguyen, 2019). Therefore, the fiscal deficit is the regular phenomenon in Vietnam and the ratio of fiscal deficit/ GDP is included in the model. Hence, the equation (8) becomes risk premium model and is expressed as follows:

$$
\begin{aligned}
\operatorname{lnriskp}_{\mathrm{t}}= & a_{0}+a_{1} \text { open }_{\mathrm{t}}+a_{2} \text { fpiv }_{\mathrm{t}}+a_{3} \text { lnstexd }_{\mathrm{t}}+ \\
& a_{4} f d_{\mathrm{t}}+\varepsilon_{\mathrm{t}}
\end{aligned}
$$

with lnriskp; open; fpiv; lnstexd; fd; $\varepsilon$, in turn, representing for $\ln \left(\frac{i-i^{*}}{1+i^{*}}\right)$, trade openness, the volatility of foreign portfolio investment, the natural logarithm of the ratio of short-term external debt/ reserves, the ratio of fiscal deficit/ GDP; error; $a_{0}$ to $a_{4}$ represent regression coefficients, $\mathrm{t}$ denotes time.

In the equation (9), open, lnstexd, fd and lnriskp are expected to have the positive relationship because the ratio of import value/ GDP, the ratio of short-term external debt/ reserves or the ratio of fiscal deficit/ GDP are higher, it means that the financing demand in foreign currency is larger and makes reduction of reserves. Therefore, probability of default as well as risk premium are higher. Meanwhile, fpiv and lnriskp are expected to have the negative relationship because the volatility of foreign portfolio investment goes in the decrease trend, it shows that capital flow is withdrawn from country and gives a signal about the unstableness of economy. Hence, probability of default as well as risk premium will be higher.

The equation (9) is regressed to estimate the parameters of $\mathrm{a}_{0}$ to $\mathrm{a}_{4}$ and find out $f$ function. Then, probability of default $(\pi)$ is calculated basing on the equation (6).

Marginal probability of default $\left(\pi_{R}\right)$ is calculated by derivative of the equation (7) in which $f$ function is determined.

\subsubsection{Optimum Reserves}

Taking the equation (2) into (1), the result is:

$$
E C=\pi C_{0}+(1-\pi) r R=\pi C_{0}+r R-\pi r R
$$

Reserves reaches the optimum level when the total cost (EC) of reserves is at the minimum. In the other words, the optimum reserves is at the level that the derivative of the total cost (EC) based on reserves (R) is zero. Taking note that $\pi$ is the function of $R$, the equation (10) can be expressed:

$$
\frac{\partial E C}{\partial R}=C_{0} \frac{\partial \pi}{\partial R}+r-r R^{*} \frac{\partial \pi}{\partial R}-\pi r=0
$$

Taking the equation (3) into (11), the new equation is:

$$
\pi_{\mathrm{R}}\left(C_{0}-r R^{*}\right)+(1-\pi) r=0
$$

By calculating $R^{*}$ from the equation (12), the optimum reserves model is as follows:

$$
R^{*}=\frac{1-\pi}{\pi_{\mathrm{R}}}+\frac{C_{0}}{r}
$$

In the above model, the estimation method for variables of $\mathrm{C}_{0}, \mathrm{r}, \pi$ and $\pi_{\mathrm{R}}$ is clearly presented, so it is easy to calculate the optimum reserves. 


\subsection{Data}

The Vietnam's optimum reserves is estimated basing on the quarterly data in the period of $2005-2017$. The data of reserves and import value is collected at International Financial Statistics (IFS); GDP data is extracted at the source of General Statistics Office of Vietnam (GSO); the data of foreign portfolio investment is taken at Bloomberg; the data of fiscal deficit is collected at Ministry of Finance in Vietnam, the data of LIBOR 3-month rate for USD which is at the source of Intercontinental Exchange (ICE) represents the risk-free rate. The lending rate of VND is collected at IFS, representing both the interest rate when lending a risky country and opportunity cost. However, quarterly data of short-term external debts is not available. Hence, basing on the quarterly data of total external debts and the yearly ratio of short term external debts/ total external debts collected from the source of Asian Development Bank (ADB) and World Bank, the data of short term external debts is interpolated into the quarterly series.

\subsection{Econometric Method}

This paper uses the following econometric methods processed on Stata 13.0 software.

\subsubsection{HP Filter (Hodrick-Prescott Filter) Method}

The loss of Vietnamese GDP, which denotes the loss due to country's default, is measured by the difference between the total actual GDP and the total potential GDP in the period of reduced growth speed of GDP with the calculation of potential GDP by HP Filter method. Hodrick and Prescott (1981) introduce HP Filter method and describe that the time series $y_{t}$ includes growth component $\mathrm{g}_{\mathrm{t}}$ and cyclical component $\mathrm{c}_{\mathrm{t}}$. Therefore, $\mathrm{y}_{\mathrm{t}}$ can be replaced by growth component $g_{t}$ with the smoother graph but it is not much different with $\mathrm{y}_{\mathrm{t}}$. Applying HP Filter method, potential GDP $\left(\operatorname{gdp}^{\mathrm{T}}\right)$ is determined by the following formula:

$$
\begin{aligned}
& \min _{\left\{g d p^{\mathrm{T}}\right\}_{t=-1}^{T}}\left\{\sum_{t=1}^{T}\left(g d p_{\mathrm{t}}-g d p^{\mathrm{T}}\right)^{2}+\lambda \sum_{t=1}^{T}\left[\left(g d p^{\mathrm{T}}{ }_{\mathrm{t}}-\right.\right.\right. \\
& \left.\left.\left.g d p_{\mathrm{t}-1}^{\mathrm{T}}\right)-\left(g d p^{\mathrm{T}}{ }_{\mathrm{t}-1}-g d p^{\mathrm{T}}{ }_{\mathrm{t}-2}\right)\right]^{2}\right\}
\end{aligned}
$$

$\lambda$ is smoothing parameter and $\lambda=1600$ if the data is quarterly.

\subsubsection{ARCH (Autoregressive Conditional Heteroscedasticity) Model}

ARCH model is used for estimating the standard deviation of foreign portfolio investment as proxy for the volatility of foreign portfolio investment. This is one of independent variables in the risk premium model. ARCH means autoregressive conditional heteroscedasticity and implies that the volatility of data in latter period depends on the information of previous period. Basing on $\mathrm{ARCH}(1)$ model introduced by Engle (1982), the conditional variance $h_{t}$ (square of standard deviation) of foreign portfolio investment series is written as:

$$
\begin{gathered}
f p i_{\mathrm{t}}=\mu+\varepsilon_{\mathrm{t}} \text { vớ } i \varepsilon_{\mathrm{t}} / \psi_{\mathrm{t}-1} \sim N(0, h t) \\
h_{\mathrm{t}}=\alpha_{0}+\alpha_{1} \varepsilon^{2}{ }_{\mathrm{t}-1}+u_{\mathrm{t}}
\end{gathered}
$$

in which, fpi is foreign portfolio investment, $\alpha_{0}>$ $0, \alpha_{1} \geq 0$ because the variance $h_{t}$ is always positive and $\alpha_{1}<1$ for ensuring that $\mathrm{h}_{\mathrm{t}}$ is stationary.

\subsubsection{ADF (Augmented Dickey-Fuller) Method for Stationarity Test}

$\mathrm{ADF}$ is used for stationarity test on variables in the risk premium model. Stationarity test is important because the stationary series ensure that the forecast becomes confident and the regression is not spurious. To be help the ADF method more confident, it needs to test at the optimum lag of series which is determined by the minimum AIC (Akaike Information Criteria). According to Gujarati (2011), ADF method can test for three forms of time series data with three following equations.

Firstly, the form of random walk:

$$
\Delta Y_{\mathrm{t}}=\psi Y_{\mathrm{t}-1}+\sum_{i=1}^{p} \beta i \Delta Y_{\mathrm{t}-\mathrm{i}}+u_{\mathrm{t}}
$$

Secondly, the form of random walk with drift:

$$
\Delta Y_{\mathrm{t}}=\mu+\psi Y_{\mathrm{t}-1}+\sum_{i=1}^{p} \beta i \Delta Y_{\mathrm{t}-\mathrm{i}}+u_{\mathrm{t}}
$$

Thirdly, the form of random walk with drift around a deterministic trend:

$$
\Delta Y_{\mathrm{t}}=\mu+\lambda_{\mathrm{t}}+\psi Y_{\mathrm{t}-1}+\sum_{i=1}^{p} \beta i \Delta Y_{\mathrm{t}-\mathrm{i}}+u_{\mathrm{t}}
$$

The test hypotheses: $\mathrm{H}_{0}: \psi=0$ and $\mathrm{H}_{1}: \psi<0$. If $\mathrm{H}_{0}$ is rejected, $\mathrm{Y}_{\mathrm{t}}$ series is stationary. But if $\mathrm{H}_{0}$ is not rejected, $\mathrm{Y}_{\mathrm{t}}$ series is not stationary or has unit root.

\subsubsection{ARDL (Autoregressive Distributed Lag) Model}

When ADF tests are done, all variables in the risk premium model are stationary at both $\mathrm{I}(0)$ and $\mathrm{I}(1)$ or at the different order, so the application of ARDL model is suitable for determining the long run equation, representing 
the risk premium model. According to Kripfganz and Schneider (2016), the risk premium model - the equation (9) - can be written as ARDL model in the following form of error correction.

$$
\begin{aligned}
\Delta \text { lnriskp }_{\mathrm{t}}= & c_{0}+c_{1} t-\alpha\left(\text { lnriskp }_{\mathrm{t}-1}-\theta_{1} \text { open }_{\mathrm{t}-1}-\right. \\
& \left.\theta_{2} \text { fpiv }_{\mathrm{t}-1}-\theta_{3} \operatorname{lnstexd~}_{\mathrm{t}-1}-\theta_{4} \text { fd }_{\mathrm{t}-1}\right)+ \\
& \sum_{i=1}^{p-1} \psi_{\text {lnriskpi }} \Delta \text { lnriskp }_{\mathrm{t}-\mathrm{i}}+\omega_{1} \Delta \text { open }_{\mathrm{t}}+ \\
& \omega_{2} \Delta \text { fpiv }_{\mathrm{t}}+\omega_{3} \Delta \operatorname{lnstexd~}_{\mathrm{t}}+\omega_{4} \Delta \text { fd }_{\mathrm{t}}+ \\
& \sum_{i=1}^{q-1} \psi_{\mathrm{openi}} \Delta \text { open }_{\mathrm{t}-\mathrm{i}}+\sum_{i=1}^{q-1} \psi_{\mathrm{fpivi}} \Delta \text { fpiv }_{\mathrm{t}-\mathrm{i}}+ \\
& \sum_{i=1}^{q-1} \psi_{\text {stexdi }} \Delta \text { lnstexd }_{\mathrm{t}-\mathrm{i}}+\sum_{i=1}^{q-1} \psi_{\mathrm{fdi}} \Delta f d_{\mathrm{t}-\mathrm{i}}+u_{\mathrm{t}}
\end{aligned}
$$

The long run equation or the risk premium model is:

$$
\begin{aligned}
\operatorname{lnriskp}_{\mathrm{t}}= & \theta_{1} \text { open }_{\mathrm{t}}+\theta_{2} \text { fpiv }_{\mathrm{t}}+\theta_{3} \text { lnstexd }_{\mathrm{t}}+ \\
& \theta_{4} f d_{\mathrm{t}}\left[+c_{0} / c_{1} t\right]
\end{aligned}
$$

with $c_{1} t$ denotes the time trend.

\section{Results and Discussion}

\subsection{Estimation of the Loss due to Country's Default}

The Figure 1 shows that the potential GDP estimated by HP Filter method is compared with the actual GDP. In almost period of Q1/2008 - Q2/2013, the actual GDP line lies below the potential GDP line. Accordingly, the difference between the total actual GDP and the total potential GDP during this reducing period is $8,582,103,000$ USD. This is the loss of Vietnamese GDP from the influence of the financial crisis 2008 as proxy for the loss due to country's default.

Table 1: Result of Stationarity Test for the Variables by ADF Method

\begin{tabular}{|c|c|c|c|c|}
\hline Variable & $\begin{array}{c}\text { Minimum } \\
\text { AIC }\end{array}$ & $\begin{array}{c}\text { Optimum } \\
\text { lag }\end{array}$ & $\begin{array}{c}\mathbf{Z}(\mathbf{t}) \\
\text { value in } \\
\text { ADF test }\end{array}$ & $\begin{array}{c}\text { Stationary } \\
\text { order }\end{array}$ \\
\hline lnriskp & -80.32931 & 3 & -4.026 & $\mathrm{I}(1)^{* * *}$ \\
\hline open & -67.86557 & 5 & -2.207 & $\mathrm{I}(0)^{* *}$ \\
\hline fpiv & 45.41102 & 7 & -3.696 & $\mathrm{I}(0)^{* * *}$ \\
\hline Instexd & -32.18169 & 5 & -1.638 & $\mathrm{I}(0)^{*}$ \\
\hline fd & -209.9267 & 4 & -2.922 & $\mathrm{I}(0)^{* * *}$ \\
\hline
\end{tabular}

The sign of $* * *, * * *$ denotes the significant level of $10 \%, 5 \%, 1 \%$ respectively.

\subsection{Estimation of the Probability of Default}

The probability of default is estimated from the risk premium model - the equation (9).

\subsubsection{Estimation of the Volatility of Foreign Portfolio Investment by ARCH Model}

The foreign portfolio investment series (fpi) has ARCH effect and ARCH(1) model is found to be suitable with the conditional variance $\left(h_{t}\right)$ equation as follows:

$$
\begin{gathered}
f p i t=14.57145+\varepsilon \mathrm{t} \\
{[134.36]^{* * *}} \\
h \mathrm{t}=0.0556722+0.9886661 \varepsilon^{2} \mathrm{t}-1 \\
{[1.27] \quad[2.34]^{* *}}
\end{gathered}
$$

The sign of $*, * *, * * *$ denotes the significant level of $10 \%$, $5 \%, 1 \%$ respectively.

The conditional variance $h_{t}$ is estimated from the above equation. The standard deviation of foreign portfolio investment series, as proxy for the volatility of foreign portfolio investment (fpiv), is the square root of $h_{t}$.

\subsubsection{Result of Stationarity Test for All Variables in the Risk Premium Model}

Table 1 describes the result of stationarity test for all variables in the risk premium model by ADF method.

All independent variables are stationary at $\mathrm{I}(0)$ with the form of random walk with drift for time series data. Meanwhile, the dependent variable of lnriskp is stationary at I(1). Because all variables are stationary at different order, regression by ARDL model is suitable for this case to find out the long run equation which represents the risk premium model.

\subsubsection{Results of Regression by ARDL Model}

Firstly, it is determined that ARDL model with the optimum lags based on minimum AIC is the model of ARDL(3 42214$)$. Continuously, the model of ARDL(3 42 $14)$ is regressed in the form of error correction. Consequently, the long run equation or the risk premium model is found out with the regression coefficients in Table 2.

Table 2 shows that all regression coefficients in the long run equation is significant. In the other words, all variables of open, fpiv, lnstexd, fd influence risk premium and probability of default. Moreover, positive and negative signs of all coefficients in the risk premium model are correct to the expectation.

In summary, after regression of ARDL model, the long run equation or the risk premium model is written as follows: 
$\mathrm{f}=\ln _{\text {riskp }}=-0.089 *$ time $+2.434 *$ open $_{\mathrm{t}}-0.163 * \mathrm{fpiv}_{\mathrm{t}}+$ $0.830 * \operatorname{lnstexd} d_{t}+13.198 * \mathrm{fd}_{\mathrm{t}}$

To ensure that ARDL model is confident, it needs to do the bounds test introduced by Pesaran, Shin and Smith (2001) for confirming that variables really have the long run relationship. The test results shows that $\mathrm{F}$ value $=4.688$ is higher than the critical value of upper bound $=4.43$ at the significant level of 5\%. This means that the hypothesis $\mathrm{H}_{0}$ is rejected or in other words, there is the long run relationship of variables in the risk premium model. Besides, the other diagnostic tests shows that ARDL model has no autocorrelation and no heteroscedasticity, the white noise of residuals as well as the cumulative sum of square of recursive residuals inside the standard band at the significance of $5 \%$. Therefore, the risk premium model is confident of using. With determined $f$ function like the equation (14), it completely estimates the probability of default $(\pi)$ basing on the equation (6).

Table 2: Long Run Equation in ARDL Model

\begin{tabular}{|c|c|c|c|c|c|}
\hline & \multicolumn{5}{|c|}{ Independent variables } \\
\cline { 2 - 6 } & Time trend & open & fpiv & Instexd & fd \\
\hline \multirow{2}{*}{ Regression coefficients } & -0.0893224 & 2.434472 & -0.1635649 & 0.8303476 & 13.198 \\
& {$[-6.26]^{* * *}$} & {$[2.58]^{* *}$} & {$[-6.72]^{* * *}$} & {$[6.89]^{* * *}$} & {$[2.46]^{* *}$} \\
\hline
\end{tabular}

The sign of $*, * * * * *$ denotes the significant level of $10 \%, 5 \%, 1 \%$ respectively

\subsection{Estimation of Marginal Probability of Default}

Taking the equation (14) into the equation (7), the risk premium model can be written:

$\ln \left(\frac{\pi}{1-\pi}\right)_{\mathrm{t}}=-0.089 *$ time $+2.434 *$ open $_{\mathrm{t}}-0.163 *$ fpiv $_{\mathrm{t}}+$ $0.830 * \operatorname{lnstexd} d_{t}+13.198 * \mathrm{fd}_{\mathrm{t}}$

Marginal probability of default $\left(\pi_{R}\right)$ is calculated by derivative of the equation (15) based on reserves $(R)$, the result is:

$$
\pi_{\mathrm{R}}=-\pi(1-\pi) \frac{0.8303476}{R}
$$

The result shows that marginal probability of default $\left(\pi_{\mathrm{R}}\right)$ $<0$, completely right to the theory about the negative relationship between probability of default and reserves.

\subsection{Estimation of Optimum Reserves in Vietnam}

Taking the equation (16) into the equation (13), the Vietnamese optimum reserves function can be written:

$$
R^{*}=\frac{C_{0}}{r}-\frac{R}{0.8303476 * \pi}
$$

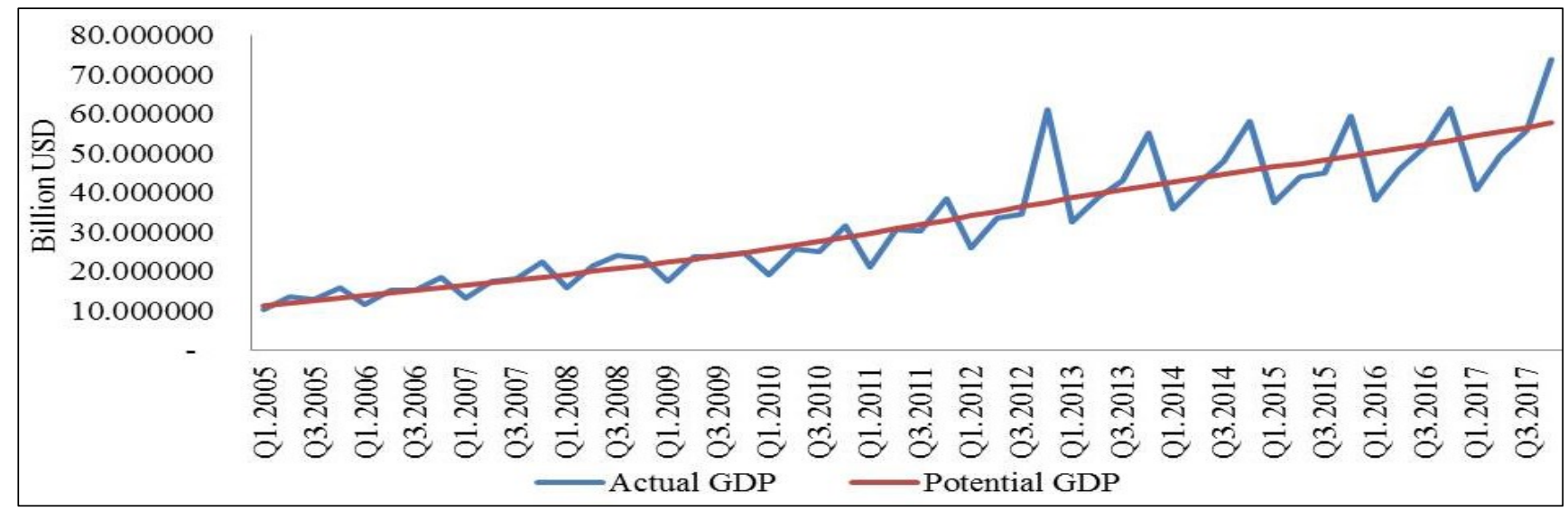

Figure 1: Vietnam's Actual GDP and Potential GDP in the Period of 2005 - 2017

The optimum reserves in Vietnam is calculated basing on the equation (17) with the determined opportunity cost (r), the loss due to country's default $\left(C_{0}\right)$, probability of default $(\pi)$ and reserves (R). The equation (17) shows that the 
optimum reserves has positive relationship with $C_{0}$ and $\pi$ as well as negative relationship with $\mathrm{r}$ and $\mathrm{R}$. After the optimum reserves is estimated, it is compared with the actual reserves in Figure 2.

Figure 2 shows that during the period of $2005-2017$, the optimum reserves is always much higher than the actual reserves. Only at two points of Q3/2008 and Q4/2017, the optimum reserves is just lower than the actual one. In Q3/2008, opportunity cost increases sharply to $20.10 \%$ - the highest level of research period. Because opportunity cost has negative relationship with the optimum reserves, it makes the optimum reserves strongly reduce at the level of 10 billion USD and is lower than the actual reserves. In Q4/2017, the actual reserves raises much and reaches 49 billion USD. With the negative relationship between the optimum reserves and the actual one, this at once causes a drop of the optimum reserves at the level of 39 billion USD.

Briefly, in the end of period - Q4/2017, although the actual reserves in Vietnam is higher than the optimum one, it is not enough safe for Vietnam because during all period, the actual reserves is always lower than the optimum. Therefore, Vietnam should continue to accumulate reserves but Vietnam does not need push strongly the accumulating speed.

\section{Conclusions and Policy Implications}

Reserves plays the important role in protecting the economy from internal or external shocks. Therefore, strong accumulation of reserves and estimation of optimum reserves are the interested issues of government. This paper estimates the Vietnam's optimum reserves with the quarterly data in the period of $2005-2017$ basing on application of the model of Ben-Bassat and Gottlieb (1992). This model is suitable to use for developing countries because it estimates optimum reserves basing on the approach of cost-benefit from holding reserves and sovereign risk concerning developing countries. The cost of reserves is the opportunity cost when holding reserves measured by the lending rate of VND. The benefit of reserves is the loss due to country's default in case that there is no reserves to finance external debt payment. The loss due to country's default is represented by the loss of Vietnamese GDP in the period of reducing growth speed of GDP from Q1/2008 to Q2/2013 because of the global financial crisis in 2008 with the loss value of 8,582,103,000 USD. The probability of default is estimated from the risk premium model. In this model, the empirical results show that trade openness, the volatility of foreign portfolio investment, the ratio of short term external debt/ reserves and the ratio of fiscal deficit/ GDP influence Vietnamese risk premium and probability of default. With such variables, the optimum reserves model in Vietnam reveals that optimum reserves has positive relationship with the loss due to country's default and probability of default as well as negative relationship with opportunity cost and actual reserves.

This paper finds that that the optimum reserves in Vietnam is always higher than the actual one during the period, except Q4/2017 - the end of period. Basing on the result, it comes to the conclusion that Vietnam needs to continue increasing reserves in the future but Vietnam is not necessary to push quickly the speed of increasing reserves. In addition, Vietnam has to control the optimum reserves because if optimum reserves raises highly, it means that actual reserves has to raise similarly and this becomes a burden to Vietnam.

These conclusions provide some policy implications for Vietnamese government. Firstly, to increase actual reserves as well as control optimum reserves, it is necessary to decrease the opportunity cost and probability of default according to the optimum reserves model in Vietnam. It means that The State Bank of Vietnam needs to lower the lending rate of VND as proxy for the opportunity cost to a suitable extent. At the same time, basing on the result of the risk premium model, Vietnamese authorities can reduce the probability of default by controlling imports, managing effectively short term external debts, decreasing fiscal deficit, encouraging but controlling closely foreign portfolio investment. Secondly, because it is unnecessary to hasten the reserves accumulation, The State Bank of Vietnam should make the prior estimation of the optimum reserves for the next year in order to get the appropriate plan of accumulating reserves during the year.

Therefore, the contribution of this paper is to provide the first empirical evidence in Vietnam for the model of BenBassat and Gottlieb (1992) with the method of estimating the optimum reserves basing on the cost-benefit from holding reserves and sovereign risk. Through the abovementioned method, the other contribution of this paper is to supplement one method into the method set of estimating the optimum reserves so that Vietnam can choose to apply. From this paper, the further research in the future can reinforce the accuracy and the reliability of result by adding more explanatory variables in the risk premium model as well as calculating the opportunity cost by two interest rates as proxy for the profit of non-risk assets and risky ordinary assets.

\section{References}

Ben-Bassat, A., \& Gottlieb, D. (1992). Optimal international reserves and sovereign risk. Journal of International Economics, 33(1992), 345-362.

Calvo, G. A., Izquierdo, A., \& Loo-Kung, R. (2012). Optimal 
holdings of international reserves: self-insurance against sudden stop (NBER Working Paper No. 18219). National Bureau of Economic Research, Inc. DOI: 10.3386/w18219.

Engle, R. F. (1982). Autoregressive conditional heteroscedasticity with estimates of the variance of United Kingdom Inflation. Econometrica, 50(4), 987-1008.

Gujarati, D. (2011). Econometrics by example (1st ed.). London, UK: Palgrave Macmillan.

Guan, F. E., \& Lau, W. Y. (2018). Triffin Dilemma and international monetary system: evidence from Pooled Mean Group Estimation. Journal of Asian Finance, Economics and Business, 5(2), 5-14.

http://doi.org/10.13106/jafeb.2018.vol5.no2.5

Heller, H. R. (1966). Optimal international reserves. The Economic Journal, 76(302), 296-311.

Hodrick, R. J., \& Prescott, E. C. (1981). Post-war U.S. business cycles: An empirical investigation (Discussion Paper No. 451). Northwestern University, The Center for Mathematical Studies in Economics and Management Sciences (CMS-EMS).

IMF. (2011). Assessing reserve adequacy. Washington, DC: International Monetary Fund. Retrieved June 15, 2019 from https://www.imf.org/external/np/pp/eng/2011/021411b.pdf

IMF. (2012). International reserves: IMF concerns and country perspectives. Washington, DC: International Evaluation Office, International Monetary Fund. Retrieved June 15, 2019 from https://www.oecd.org/derec/imf/InternationalReserves\%20IM F2013_Main_Report.pdf

Kripfganz, S., \& Schneider, D. C. (2016). ARDL: Stata module to estimate autoregressive distributed lag models. Paper presented at the Stata Conference, Chicago, July 29, 2016. Retrieved June 15, 2019 from

https://www.stata.com/meeting/chicago16/slides/chicago16_kr ipfganz.pdf
Nguyen, H. H. (2019). The role of state budget expenditure on economic growth: empirical study in Vietnam. Journal of Asian Finance, Economics and Business, 6(3), 81-89. https://doi.org/10.13106/jafeb.2019.vol6.no3.81

Oputa, N. C., \& Ogunleye, T. S. (2010). External reserves accumulation and the estimation of the adequacy level for Nigeria. Economic and Financial Review, 48(3), 1-29.

Ozyildirim, S., \& Yaman, B. (2005). Optimal versus adequate level of international reserves: evidence for Turkey. Applied Economics, 37(13), 1557-1569.

Pesaran, M. H., Shin, Y., \& Smith, R. J. (2001). Bounds testing approaches to the analysis of level relationships. Journal of Applied Econometrics, 16(3), 289-326.

Prabheesh, K. P. (2013). Optimum international reserves and sovereign risk: Evidence from India. Journal of Asian Economics, 28(2013), 76-86.

Tecnica, G. (2012). Optimum and adequate level of international reserves (Borradores de Economía No. 727I). Banco de la Republica, Colombia. Retrieved June 17, 2019 from https:/www.banrep.gov.co/sites/default/files/publicaciones/arc hivos/be_727I.pdf

Tule, M. K., Egbuna, E. N., Sagbamah, J. E. L., Abdusalam, S. A., Ogundele, O. S., \& Oduyemi, A. O. (2015). Determination of Optimal Foreign Exchange Reserves in Nigeria (CBN Working Paper Series CBN/WPS/01/2015/06). Central Bank of Nigeria. Retrieved June 17, 2019 from https://www.cbn.gov.ng/out/2015/ccd/determination $\% 20$ of $\% 2$ 0optimal $\% 20$ foreign $\% 20$ exchange $\% 20$ reserves $\% 20$ in $\% 20$ nige ria.pdf

Yu, H. (2018). Is currency appreciation or depreciation expansionary in Thailand? Journal of Asian Finance, Economics and Business, 5(1), 5-9. http://dx.doi.org/10.13106/jafeb.2018.vol5.no1.5 